ン*2を合成しまなた尿素は市販品を乾燥して用いた。

\section{2 反応条件}

臭化ポリメチレンシ $0.05 \mathrm{~mol}$ と尿素 $0.4 \mathrm{~mol}$ を加熱して $140^{\circ}$ 〜 $150^{\circ} \mathrm{C}$ にたもちながらはげしくかきまぜ, 反応系が均一となっ たとき加熱をやめ冷却させる。反応時間は 20４0 分である。

\section{3 実験結果}

1.3.1 臭化-ヘキサメチレン, -ヘプタメチレンと尿素との反応 生成物：反応混合物に水を加えて不溶物をこし取り， 口液に炭酸 カリウムを飽和させて析出する結晶を上記水不溶物と混合し，熱 "希エタノ一ルに溶かし不溶物を口去する。口液から析出する絬晶 を希エタノールで再結晶する。臭化へキサメチレンと尿素との反 応生成物から $\mathrm{mp} 201^{\circ} \sim 202^{\circ} \mathrm{C}$ の結晶をえた(収率 $30 \%$ )。へキ サメチレンジ尿素の交献のでは mp $205^{\circ} \sim 206^{\circ} \mathrm{C}$ である。

\section{分析值 $\mathrm{N} 27.76 \%$}

$\mathrm{C}_{8} \mathrm{H}_{18} \mathrm{~N}_{4} \mathrm{O}_{2}$ としての計算值 $\mathrm{N} \quad 27.70 \%$

臭化ヘプタメチレンと尿素との反応生成物から $\mathrm{mp} 182.5^{\circ} \sim$ $184.5^{\circ} \mathrm{C}$ の結晶が少量光られた。これはヘプタメチレンジ尿絮の 交献)の $\mathrm{mp} 182^{\circ} \mathrm{C}$ に近いが，窒素分析值は約 $2 \%$ 少ない。

どの場合でも，エタノールに溶け難い高融点の副生物がかなり 多量にえられた。これらを封管中, 濃塩酸と $170^{\circ} \sim 180^{\circ} \mathrm{C}$ に加 熱分解したのち，ベンゾィル化して $N, N^{\prime}$-ジベンゾイルヘキサ メチレンジアミンおよびーヘプタメチレンジアミンを好收率でえ た。

$N, N^{\prime}$-ジベンソイルポリメチレンジアミンの窒素分析值

$\begin{array}{ccc}\left(\mathrm{C}_{6} \mathrm{H}_{5} \mathrm{CONH}\right)_{2}\left(\mathrm{CH}_{2}\right)_{n} & \mathrm{~N}(\%) \text { 計算値 } & \mathrm{N}(\%) \text { 分析值 } \\ n=3 & 9.92 & 9.89 \\ 4 & 9.45 & 9.54 \\ 5 & 9.02 & 8.93 \\ 6 & 8.63 & 8.72 \\ 7 & 8.27 & 8.27\end{array}$

1.3.2 臭化トリメチレンと尿素との反応生成物：反応混合物に 水を加光可溶物を溶かした。不溶物は不燃性である。可溶物に 水酸化ナトリウムを加え, 還流冷却器を付して堂沸する。アンモ ニアが発生しなくなってから水蒸気蒸留し, 留出液を塩酸で酸性 にし蒸発乾固して結奛をえた（収率 $65 \%$ )。この結晶をベンゾィ ル化して $\mathrm{mp} 147.8^{\circ} \sim 149.2^{\circ} \mathrm{C}$ の結晶をえた。これは $N, N^{\prime}-シ ゙$

*1 京都大学化学研究所国近研究室からいただいた 1,6 -ヘキサンシオールを常 法によって臭䇣化して合成した。

*2 “Org. Syntheses” Coll. vol II, p. 154 (1948) 祀䣹の方法によりつ くった 1,7-ヘプタンシオールを常法によって臭素化して合成した.

6）岩倉，宇野，日化 78，1511 (1957)
ベンゾイルトリメチレンジアミンの交献7) の $\mathrm{mp} 147^{\circ} \sim 148^{\circ} \mathrm{C}$ と 一致する。

1.3.3 臭化テトラメチレンと尿素との反応生成物：反応混合物 に水を加え可溶物を溶かし口過する。不溶物は不燃性である。口 液を炭酸カリウムで飽和し，生ずる沈殿を口過する。沈殿をエタ ノールで再結晶し $\operatorname{mp~} 221^{\circ} \sim 223^{\circ} \mathrm{C}$ の結晶をえた (収率 $37 \%$ )。

分析值 $\mathrm{N} 24.53 \%$

$\mathrm{C}_{5} \mathrm{H}_{10} \mathrm{~N}_{2} \mathrm{O}$ としての計算值 $\mathrm{N} 24.54 \%$

この結晶を濃㙉酸で分解したのち, 水酸化ナトリウム溶液と塩 化 $p$ ートルェンスルホニルで処理し, 光られた結晶をエタノール で再結晶し mp $122^{\circ} \sim 123^{\circ} \mathrm{C}$ の結晶をえた。これは $N-p$-トル エンスルホニルテトラメチレンィミンの交献8) の $\mathrm{mp} 123^{\circ} \mathrm{C}$ と 一致する。

\section{分析值 N $6.35 \%$}

$\mathrm{C}_{11} \mathrm{H}_{15} \mathrm{NO}_{2} \mathrm{~S}$ としての計算值 $\mathrm{N} 6.21 \%$

上記炭酸カリウムで飽和した口液は,エタノールーエーテル混合 液 $(1: 1)$ で抽出し，抽出液を蒸発乾固してえた残分を濃塭酸て 分解した。分解物をベンゾイル化してえられた結晶をエタノール で再結晶し mp $176^{\circ} \sim 177^{\circ} \mathrm{C}$ の結晶少量をえた。これは $N, N^{\prime}$ 。 ジベンゾイルテトラメチレンジアミンの文献》) $\mathrm{mp} 177^{\circ} \mathrm{C}$ と 一致する。

1.3.4 臭化ペンタメチレンと尿素との反応生成物: 反応混合物 に水を加え可溶物を溶玑し，口液に炭酸力リウムを加える。析出 した結晶をエタノールで処理し可溶物と不溶物にわける。エタノ 一ル可溶物は浱塩酸で加熱分解したのち，水酸化ナトリウムを加 えてアルカリ性にし水蒸気蒸留を行ない，留出物に塩酸を加えて 浱縮した。これを常法によって塩化 $p$-ニトロベンゾイルで処理 し，えられた結晶をエタノールで再結晶し mp $119^{\circ} \sim 120^{\circ} \mathrm{C}$ の 結晶をえた。(収率 20\%)。

\section{分析值 N $11.91 \%$}

$\mathrm{C}_{12} \mathrm{H}_{14} \mathrm{~N}_{2} \mathrm{O}_{3}$ としての計算值 $\mathrm{N} 11.96 \%$

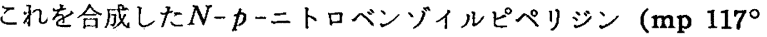
$\sim 118^{\circ} \mathrm{C}$ ) と混融した。 $\mathrm{mp} 117^{\circ} \sim 118.5^{\circ} \mathrm{C}$ 。

上記エタノール不溶物を浱塩酸で分解し, 生成物をベンゾィル 化して少量の $\mathrm{mp} 132^{\circ} \sim 133^{\circ} \mathrm{C}$ の結晶をえた。文献8 の $N, N^{\prime}$ ジベンゾイルペンタメチレンジアミンは $\mathrm{mp} 135^{\circ} \mathrm{C}$ である。

(1959 年 4 月, 日本化学会第 12 年会講演)

7) “Beilsteins Handbuch d. Org. Chem," 9, 262 (1926).

8) I. Heilbron, H. M. Bunburg, "Dictionary of Organic Compounds" (1953) London.

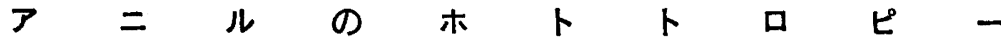

(㕷和 36 年 3 月 6 日受理)

江原望†

\section{1 緒言}

ホトトロピー，すなわち光の照射により可逆的に変色する現象
について,はいままでにかなり多くの報告があるが,その機構につ いて妥当と思われる説明の与えられているむのは少ない。ホトト 
ロピーの機構はおそらく場合によってまったく翼なるであろうと 思わ机る。

サリチリデンアニリン, およびそのある種の誘導体もホトトロ ピーを示すが、この現象はプロトトロピーによると一般に信じら れているゆ。しかしこれに対しては疑点も存在し，必ずしも替成 されていない2。しかもこれについての基礎的な研究むあまり多 くは報告されていないように思われるので, 以下のような一連の 実験を行なった。

\section{2 実}

験

試料はサリチリデンアニリンをアルコールから再結晶したもの を用い，これに紫外線をあてて黄色から赤色人と变化させ，その 前後における諸性質をしらべた。なお，照射紫外線は Corning Filter No.5879 を用いて 3300〜3800 $\AA$ 以外の領域を切った。

（1）試料を融解し，2枚の石英板にはさんで固化させ，紫外 吸収スペクトルを測定した。Le Fèvre らは照射によるスペクト ルの変化はないといっているが，明らかに $4800 \AA$ 付近に吸収極 大を生じ, 微細構造はほほ $1400 \mathrm{~cm}^{-1}$ の progression をなす四

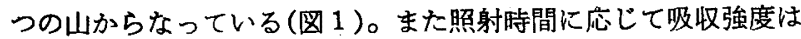

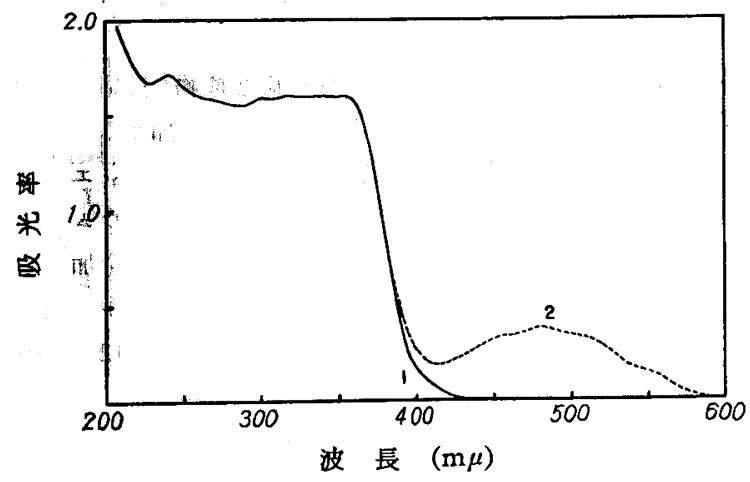

$1:$ 照射前, $2:$ 照射後

図1 サリチリデンアニリン結晶のスペクトル

かわるが，ついには 3000〜3600 凡 にあらわれている幅広い吸収 帯の約 $1 / 4$ にまで達する。しかしこのとき一般にプロトトロピー で説明されるホトトロープに見られるような近紫外部の吸収強度 の減少は認められず, $4000 \AA$ 以下の領域は完全に同一のスペクト ルを示す。

（2）岩塩板にはさんで固化させた 試料の赤外吸収スペクト ルを測定した。この物翼は強い水素結合をるち，OH 伸縮振動は きわめて幅広い吸収を与え, $\mathrm{CH}$ 伸縮振動と重なっている。とく に OH および $\mathrm{C}=\mathrm{O}$ の領域をくわしくしらべたがなんらの変化 も認め得なかった。また水酸基の挙動をよりくわしく知るため, これを重水素で置換したものを合成したが，やはり照射による変 化はまったくなかった。

（3）ある種の化合物は，低温にすると固体のみならず溶液で もホトトロピーを示すことが報告されたる。。サリリデンアニリ ンでこの可能性を見るため，エーテル，アセトン，エチルアルコ

1) M. D. Cohen, Y. Hirschberg, G. M. J. Schmidt, "Hydrogen Bonding " p. 293 (1957) Paper Symposium, Ljubljana.

2) 小林, 物性 1, 109 (1960).

3) R. Hardwick, H. S. Mosher, P. Passailaigue, Trans. Faraday Soc. $38,44(1960)$.
ール，石油エーテルに溶かし， $-60^{\circ} \mathrm{C}$ まで邻却して照射したが， 色調の変化はみられなかった。

（4）溶液のみらず，試料固体をなんらかの液体と接触させる だけでこの現象をおこし難くなる。

（5）ベンジリデンアニリンと混融したものもホトトロピーを おこす。しかしこれを粉末 X線回折法でしらべたところ，各成分 はそれぞれの相に劧かれて結晶することがわかった。

（6）サリチリデンパラクロルアニリンは従来この現象を示さ ないとされていたが，これを融解してから急冷したものは微弱な がら明らかに認め得るホトトロピーを示す。融解前後の試料の粉 末写真をとったが，両者はまったく同一の回折像を与光る。

（7）試料を照射してもESR は測定されず，受磁率は変化し ない。

（8）結晶は照射により赤変し，放置，加熱，または可視光線 の照射により退色するが，この両過程においてヨウ素の蒸気，酸 奉の影響は見られない。

（9）サリチリデンアニリンにはアルコールからら得られる黄色 板状結晶およびリグロインから得られる黄色針状結晶の二つの多 形が知られている。しかしこの他にリグロインから新たに橙赤色 の安定な結晶が得られた。低温では赤色形が安定, 高温では黄色 形が安定であり, 前者の単結晶を加熱して行くと $33^{\circ} \mathrm{C}$ 付近で後 者への転移が始まり， $35^{\circ} \mathrm{C}$ では比較的すみやかである。このと き結晶はこまかい睡裂を生ずる。また黄色形を低温にたもつと赤 色形へと変化する。赤色形自身の融点は測定できないが，これを 加熱して転移させたものと黄色形は同一の融点 $50^{\circ} \mathrm{C}$ を示す。赤 色形は強い算光をむち，ホトトロピーを示さない。黄色形および 赤色形を加熱転移させたものはともに螢光をもたず, ホトトロピ 一を示す。

ワイセンベルグ写真をとった結果，両形はともに斜方晶形に属 するが，黄色形の単位格子は赤色形のそれの一つの相をほほ 2 倍 にしたような大きさをもち，空間群はまったく異度ることがわか った。しかし結晶構造および分子構造の間にはなんらかの特殊な 関係があるように思われる。

\section{3 考察}

Le Fèvre ${ }^{3)}$ のいうように，ホトトロピーを分子間水絜移動に よるエナミン椿造の生成に州するとすれば，分子間に水糸結合が

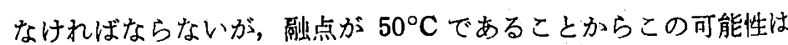
少ないと思われる。

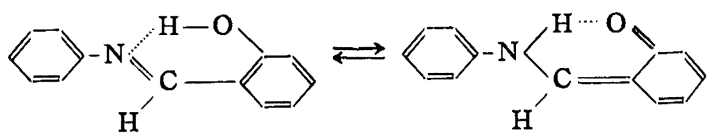

また溶液と結晶の赤外吸収スペクトルの比挍から，水素結合の 様相がこの两状態でほとんど差異がないことが明らかであり，結 晶においてむやはり分子内水素結合のままであろう.と思われる。 むし分子内水素移動がおこるとすれば，置換基の影響が系統的で ないこと，またホトトロピーの量子収率がおそらく1よりはるか に大きいことせの説明がつかない。

つぎに, 赤色形の紫外吸収スペクトルの強度から考え，もし工 ナミン形に起因するとすれば少なくとも $5 \%$ ，妥当な值として

4) G. Lindemann, Z. wiss. Phot. 50 II, 347 (1955). 
12〜15\% の変化が おこっていなければならない。それならば近 紫外部の吸収強度は減少すべきであり, また赤外吸収に当然変化 がおこるはずであり，この点も説明困難である。

赤化した結晶は退色が比較的すてみやかであるため紫外偏光スペ クトルの測定はまだ行なうに至っていないが，微細構造の分離が かなり大きい点を利用して偏光顕微鏡による観察を行なった。し かし結晶粙方向による色調のちがいはまったく見られない。した， がって $1400 \mathrm{~cm}^{-1}$ の間隔をもつ構造はおそらく振動構造であっ て, Davydov 分裂ではないと思われる。これは ○一および $p$-キ タン類の $n-\pi$ 遥移州から観察される励起状態における $\mathrm{C}=\mathrm{O}$ の振 動と大きく異なっていて,もしエナミン構造とのーキノンの電子状 態に大差がないとすれば，この微細構造は $\mathrm{C}=\mathrm{O}$ すなわちエナミ ン構造によるのではなく, むしろ $\mathrm{C}=\mathrm{N}$ すなわちアゾメチン棈造 によるのではないかと思われる。

イオンラジカルの生成も受磁率, ESR の結果から否定される。 また寿命の長い三重項状態になると考えることも受磁率の变化が ないこと，また退色過程のヒン度因子がかなり大きいこといなど から否定される。

溶液との接触によりホトトロピーがおさえられることから，結 晶表面の特異性がこの現象に関係があるようにも思われる。また 同一のX線回折像を与える二つの結晶があるいはホトトロピーを 示し，または示さないという事実は，結晶の不斉または久宿がこ れに関与するかも知れないという予想を与える。

ホトトロピーの原因はいまだ不明であるが，可能な説明として つきのいくつかが考えられる。

1）ベンジリデンアニリンについて著者はさきに非平面構造を 提出したが5)，もしサリチリデンアニリンにこの事实がありとす

5) N. Ebara, Bull. Chem. Soc. Japan 33, 534 (1960).

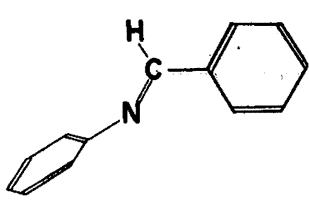

れば，結晶中の一部の分子がそのべ ンゼン核の傾きをある程度かえた状 態または平面構造をとる状態が準 安定となる可能性もなしとしないで あろう。このとき窒素の非結合性軌 道のエネルギーは高まり，アルデヒド側の $\pi$ 軌道はアニリン側の それと混じてそのエネルギーは低まり， $\boldsymbol{n}$ - $\boldsymbol{\pi}$ 吸収帯が長波長側に あらわれてくるであろう。これがホトトロピーの原因とも考えら れる。ただし水菜結合の存在，また吸収強度が大きすぎる点に問 題は残るかも知れない。

2）このような変化した分子が結晶中で 1 種の不純物準位をつ くり，これによる吸収があらわれるかも知れない。

3）もしも矢陮が関与するのであれば，そのまわりの分子が特 殊な配置をとり，たとえば双極子モーメントのベクトルがここに 指向して，これが 1 種の色中心として働らくようなことがあるか も知れない。完全な色中心と考えることは受磁率, 紫外吸収強度 の結果から承認し難いが，なんらかの現象がここでおこることを 考虑からはずすかけには行かないであろう。

4) 赤色の安定な結晶は平面棧造をとった分子の結晶かも知れ ない。

以上の諸点の解明のために，結晶解析を基礎とする研究を行な いつつある。

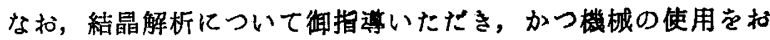
許しいただいた東京大学物性研究所斎藤喜彦教授，ならびに電子 状態の諸問題に関し多くの御教示をいただき，かつ機械の使用を 扣許しいただいた東京大学物性研究所長倉三郎教授に深い感謝の 意を表明する。

\section{研 究 速 報}

\section{気相におけるア七トンの光化学反応}

(昭和 36 年 2 月 28 日受理)

中村政宣・中村隻・堤繁罗

気相中でアセトンの紫外線による光分解反応をおこなったとこ ろ, 少量の白色結晶が単跳され, 赤外線吸収スペクトル, 元素分 析，分子量測定などの結果から $\mathrm{C}_{24} \mathrm{H}_{50}$ に相当するパラフィンで あることが明らかにされた。

従来類似の反応は数多く報告されている1が，パラフィン生成 の事実に関しては類例を見ないためとりあえず以下に報告する。

\section{1) 反応装置}

硬質ガラス製反応管 (内径 $30 \mathrm{~mm}$, 長さ $800 \mathrm{~mm}$, 加熱部分 $415 \mathrm{~mm})$ をもちいる通常の流通法によった。

光源として低压水銀灯 $(6000 \mathrm{~V} 20 \mathrm{~mA})$ 発光部分 $500 \mathrm{~mm}$ を

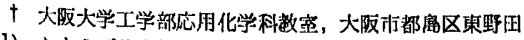

1) たとえば代表的なものとして，R. G. W. Norrish, M. E. S. Appleyard,

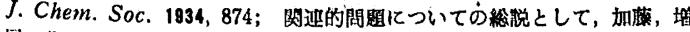
琶, 化学の敛城 12,9 (1958).
もちいた。

\section{2）反応条件および反応生成物}

反応温度 $100^{\circ}, 150^{\circ}, 250^{\circ}, 300^{\circ}, 350^{\circ}, 500^{\circ} \mathrm{C}$ (おのおの $\pm 10^{\circ} \mathrm{C}$ ）の各温度で原料供給速度 $35 \sim 36 \mathrm{cc} / \mathrm{hr}$ の条件下でおこ なった。

変化率は低く $250^{\circ}, 300^{\circ} \mathrm{C}$ の場合でも $8 \%$ 程度であった。 反応生成物としては従来の報告2にある一酸化炭素, メタン, エタンおよびジアセチルなどがガスクロマトグラフィーにより検 出された。

パラフィンの生成量はほとんど反応温度に関係なく，供給アセ

2）代表们なるのとして，R. G. W. Norrish, M. E. S. Appleyard, J. Chem. Soc. 1934, 874; W.. A. Noyes, Jr., L. M. Dorfmann, $J$.

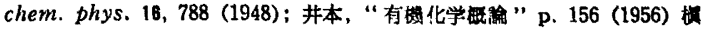
洁. 